\title{
THE EXPERIMENTAL AND NUMERICAL STUDY OF THE FORCES DURING THE INCREMENTAL FORMING OF TITANIUM SHEETS
}

\author{
(c) 2021 E.V. Markova, A.M. Al Darabseh, I.E. Daba’bneh, A.R. Ahmed \\ Institute of Aviation Technology and Management, \\ Ulyanovsk State Technical University, Ulyanovsk, Russia
}

The article was received on 17.11.2020

\begin{abstract}
Incremental forming is a rapid prototyping process that allows sheets to be formed without using forming tools, using a numerically controlled machine tool. A wide variety of shapes can be generated with this process. The objective of this work is to study through experimental tests and numerical simulations the behavior of ASTM grade 2 titanium during incremental point forming (SPIF). A Spinner MFG850 machining center from ISET in JENDOUBA coupled to a multi-component force sensor FN7325 was used for the forming of thin sheets by this process. As the diameter of the punch and its incremental movement are parameters having a direct effect on the forming force, tests with diameters of the punches dp varying between 10 and $15 \mathrm{~mm}$ and various paths made up of circular movements in the horizontal plane have been carried out experimentally. Numerical simulation is carried out in large elastoplastic deformations with ABAQUS/explicit. Comparisons of the evolution of the forming force for different values of the diameter of the punch dp and of the displacement step $\Delta$ zare carried out. Keywords: incremental forming, titanium, finite elements, experimentation, instrumentation.
\end{abstract}

DOI: $10.37313 / 1990-5378-2021-23-1-5-10$

The incremental forming process is a sheet forming process, which locally and gradually deforms the sheet by embossing by moving a small punch whose path is controlled by a CNC machine. This process makes it possible to obtain pieces of various shapes, asymmetric or not. Good conformity of the final geometry of the part obtained is linked to the choice of several parameters such as the speed of advance and of rotation of the tool, the displacement increments, the diameter of the tool.

Titanium's properties, which are a combination of high strength, toughness, toughness, low density, and good corrosion resistance offered by various titanium alloys at low and high temperatures, allow for weight savings in space structures and other high-performance applications.

The atomic weight of titanium is 47.88 . Titanium is lightweight, strong, resistant to corrosion and available in nature. Titanium and titanium alloys possess tensile strengths from 30,000 psi to Elena Markova, PhD in Economics, Associate Professor of the Department of General Scientific Disciplines. E-mail:morozova319@yandex.ru

Al Darabseh Amer Mohammad, a Student of ASVsd-61 Group of the Department of Aircraft Engineering.

E-mail: amersamarah4@gmail.com

Daba'bneh Issa Elias, a Student of ACbd-11 Group of the Department of Aircraft Engineering.

E-mail: dababneh.issa47@gmail.com

Ahmed Ahmed Ramadan, a Student of ACbd-11 Group of the Department of Aircraft Engineering.

E-mail:flafio5000@gmail.com
200,000 psi 210-1380 MPA, which is equivalent to the strength found in most steel alloys.

Titanium is a low-density element about $60 \%$ the density of iron in which alloying can be strengthened. Titanium is a non-magnetic metal and has good heat transfer properties. Its coefficient of thermal expansion is less than that of steel and less than half of coefficient of thermal expansion of aluminum. One of titanium's beneficial properties is its high melting point of 3135 degrees Fahrenheit 1725 degrees Celsius. The melting point is about $400{ }^{\circ} \mathrm{F}$ above the melting point of steel and about $2000^{\circ} \mathrm{F}$ above that of aluminum. Titanium can be passivated and thus exhibit a high degree of immunity to attack by most mineral acids and chlorides. Titanium is non-toxic and generally biocompatible with human tissue and bone. Excellent resistance to corrosion and biocompatibility along with a strength that makes titanium and titanium alloys useful in biological, chemical, petrochemical, and marine environments. Titanium is not a good conductor of electricity. If the electrical conductivity of copper is considered to be $100 \%$, then titanium has a conductivity of $3.1 \%$. It follows from this that titanium will not be used as a major factor in good conductors. For comparison, stainless steel has $3.5 \%$ conductivity and aluminum has $30 \%$ conductivity. Electrical resistance is the opposition to the flow of electrons. Since titanium is a weak conductor, it follows that it is the fair resistor. 
The asymmetric incremental forming of AISF sheets can be divided into two forming modes depending on the number of contact points between the sheet and the tool. The most studied process and which is the subject of this work is the «SPIF: single point incremental forming» incremental forming. The principle of one-point incremental forming is shown in Figure 1. The blank placed on a die is fixed using a blank clamp. The hemispherically shaped punch rotated acts incrementally in directions defined by the path programmed on the $\mathrm{CNC}$ machine. The use of this process requires a good knowledge of the behavior of the material in order to avoid stringback phenomena. The study of this SPIF process has already been the subject of several works.

A campaign of experimental tests was carried out by measuring the forming forces during the incremental forming operation. For the measurement of the forces, a force sensor FN7325 was chosen. The tests were carried out on a numerically controlled machine using a hemispherical punch.

The machine used is a 5-axis Spinner MVC 850 machining center with a maximum power of $10 \mathrm{~kW}$ and a maximum rotation speed of $8000 \mathrm{rpm}$. This DJENDOUBA ISET machine is equipped with a siemens 840D-SL type computer.

The demand is increasing in recent times for lightweight materials and alloys for use in aerospace applications, driven by the need to produce low-weight vehicles that consume less energy and are equipped with improved fuel-efficiency that produces fewer air pollutants. Aluminum and its alloys, especially aluminum-titanium alloys, are very attractive materials for this type of application due to their high resistance to weight ratio, as well as excellent mechanical properties. Three weight ratios of titanium $(10 \%, 15 \%$, and $20 \%)$ were added to aluminum, where it was used in the manufacture of aluminum-titanium alloy. The powder metallurgy cannula was used as a manufacturing method to produce aluminum-titanium alloy. Then the samples were sintered in a horizontal vacuum tube oven for 5 hours at a temperature of $550{ }^{\circ} \mathrm{C}$. The Jordanian researcher conducted many physical and mechanical tests for aluminum titanium alloy to determine its characteristics such as measurements of true porosity and mass density, X-ray diffraction (XRD) test, scanning electron microscopy (SEM), optical microscopy (OM) test, energy dispersive spectral test (EDS), Microhardness test and wear test. The results of the Jordanian researcher showed that the proportion of titanium has an important effect on the microstructure of the aluminum-titanium alloy, as titanium acts as a softening element for the granules, and thus the aluminum grains have changed from large granules to small granules and then to fine round granules depending on the weight ratio The additive of titanium. Also, the metallic interphase, TiAl, was detected in the sintered samples, which has an important effect on increasing the resistance of aluminum titanium alloy, by reducing weight loss and thus reducing its wear rates. It has been observed that the surface of the aluminum-titanium alloy has been subjected to two types of wear mechanisms, namely the adhesion wear mechanism and the abrasive wear mechanism.

An experimental sheet holding device has been specially designed for incremental forming tests. It is made up of two blocks: a lower flange clamped on the table and a second block containing the blank to be deformed. The holding system and the CNC machine used are shown in Figure 2.

The FN7325 multi-component sensor associated with an acquisition chain provides the measurements of the forming forces during the test. This

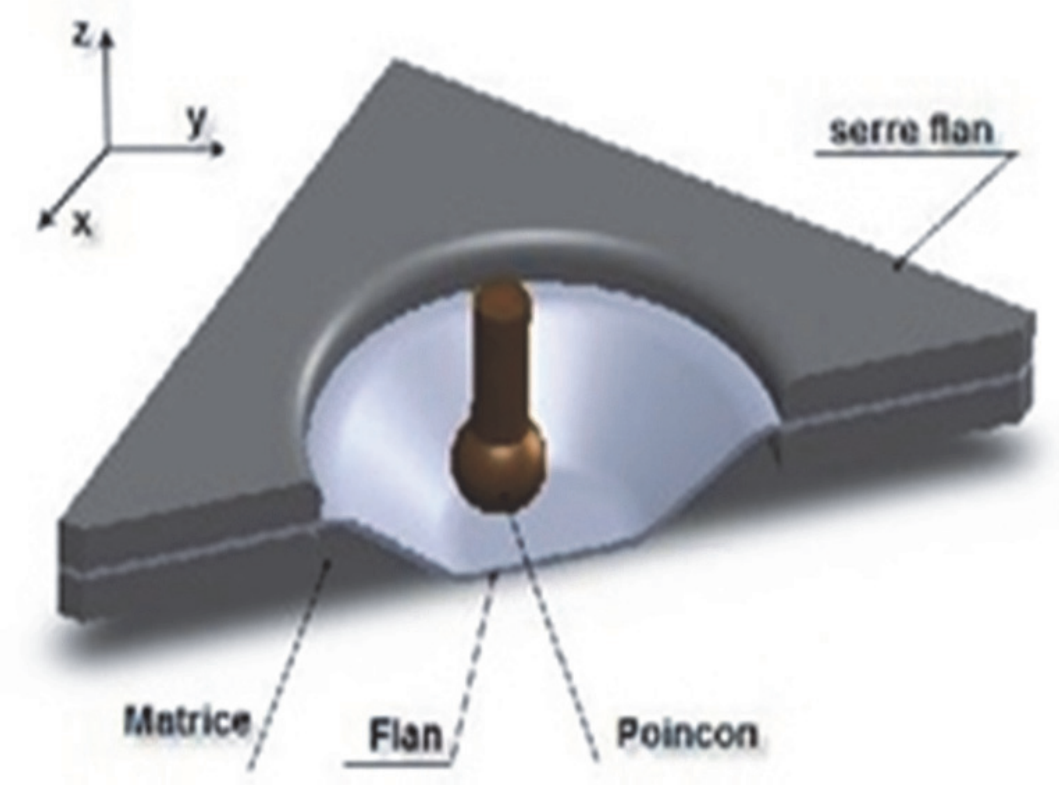

Figure 1. Schematic diagram of one-point incremental forming SPIF 

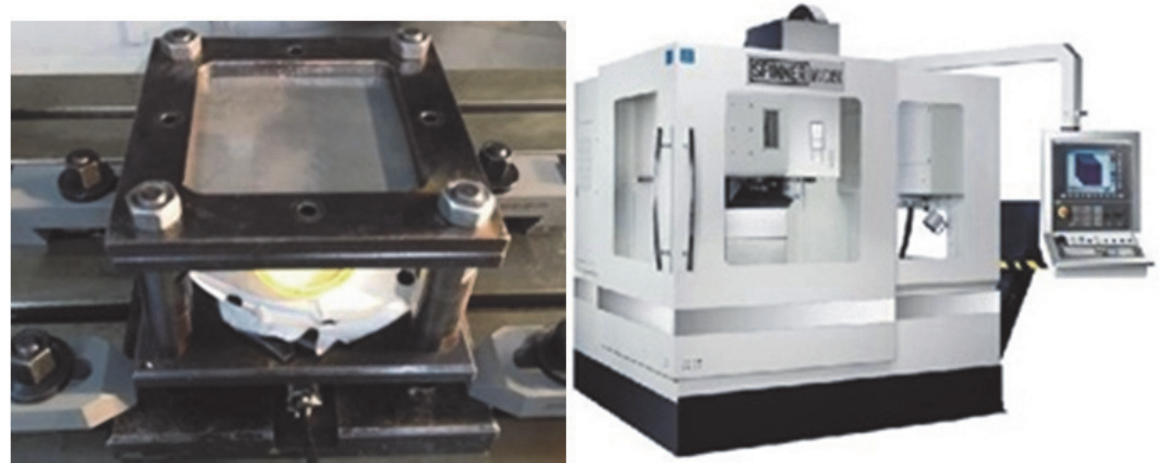

Figure 2. CNC Spinner MCV8501 machining center and SPIF incremental forming device

sensor can be used to measure forces of up to 5000 $\mathrm{N}$ and moments of up to $200 \mathrm{~N} . \mathrm{m}$ according to the $\mathrm{X}$ and $\mathrm{Y}$ axes, and forces of up to $250 \mathrm{kN}$ and moments of up to $7000 \mathrm{~N}$. $\mathrm{m}$ following the $\mathrm{Z}$ axis.

The forming of the sheet is ensured by a hemispherical punch in X160CrMoV12 steel. The latter has undergone a heat-quenching treatment at 1030 ${ }^{\circ} \mathrm{C}$ and has been air cooled to increase its hardness to $55 \mathrm{HRC}$. Two values of the diameter of the punch were studied $\mathrm{dp}=10$ and $15 \mathrm{~mm}$. Figure 3 shows the geometry of the punches and the multi-component force transducer used.

The SPIF one-point incremental forming tests were carried out on an ASTM grade 2 titanium, the mechanical characteristics of which are given in table 1 . This material is widely used for prostheses because it has great resistance and is perfectly biocompatibility with the system. bony. But little work has been done on the incremental forming of titanium, as this material is more difficult to shape and more expensive than aluminum or stainless steels. It is therefore important to find the parameters involved in improving the process in order to better understand this process and ultimately be able to lead to industrialization. The tests were carried out with sheets of size $200 * 200 \mathrm{~mm} 2$, thickness (e) 0.5 $\mathrm{mm}$ and $1 \mathrm{~mm}$. The objective was to form buckets with a tilt angle $\alpha=60^{\circ}$.
Incremental forming is performed using circular motions in the horizontal plane combined with a displacement step Dz in the vertical plane. The dimensions of the formed bucket as well as the parameters of the incremental forming test are shown in Figure 4. The punch-sheet lubricant used is cut in foil.

Two tests are performed in this study. For the first test, the value of the displacement step of the punch is $\mathrm{Dz}=0.5 \mathrm{~mm}$ and the tool diameter $\mathrm{d}_{\mathrm{p}}=15$ $\mathrm{mm}$. The measurements of the forces noted are presented in Fig. 5. Cracks appear from the 15th contour on the outer surface of the bucket.

The second test is carried out with a displacement step $\Delta \mathrm{z}=1 \mathrm{~mm}$ and a tool diameter $\mathrm{d}_{\mathrm{p}}=10$ $\mathrm{mm}$. The measurements of the noted forces are presented in figure 6 . As for the first test, cracks appear but from the 8th turn. These results are consistent with work in which a limit angle of inclination of the wall of $56^{\circ}$ is found, from which damage occurs.

As can be seen from these curves, the forces to shape titanium sheets are of the order of $2000 \mathrm{~N}$ and they are greater than those of aluminum (around $800 \mathrm{~N}$ ). Care in the choice of the design machine is therefore necessary when forming titanium sheet in order not to damage the material. In Figure 6, we can note that the surface condition of the part is not optimal. Optimization of process parameters is necessary in order to improve the surface finish of the formed parts.
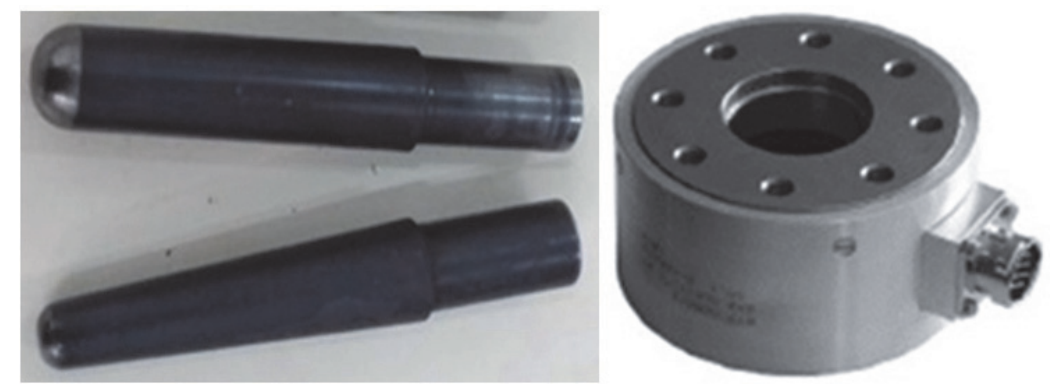

Figure 3. The tool steel punches $(\mathrm{d}=10$ and $15 \mathrm{~mm})$ and the multi-component force transducer FN73252

Table 1. The mechanical characteristics of Titanium T40

\begin{tabular}{|c|c|c|c|c|c|}
\hline Material & $\mathrm{E}(\mathrm{GPa})$ & $v$ & $\mathrm{Rp} 0.2(\mathrm{MPa})$ & $\mathrm{Rm}(\mathrm{MPa})$ & $\mathrm{A} \%$ \\
\hline ASTM grade 2-T40 titanium & 105 & 0.35 & 210 & 350 & 10 \\
\hline
\end{tabular}




\begin{tabular}{|l|l|}
\hline \multicolumn{2}{|c|}{ Conditions of realization } \\
\hline Material & T40 \\
\hline Large diameter $Ø \mathrm{D}$ & $100 \mathrm{~mm}$ \\
\hline Height h & $25 \mathrm{~mm}$ \\
\hline Thickness e & $0.5 \mathrm{~mm}$ \\
\hline Cone angle $\alpha$ & $60^{\circ}$ \\
\hline Increments $\Delta z$ & $0.5 \mathrm{~mm}$ and $1 \mathrm{~mm}$ \\
\hline Punch diameter $\mathrm{d}_{p}$ & $10 \mathrm{~mm}$ and $15 \mathrm{~mm}$ \\
\hline Rotation speed $\mathrm{N}$ & $800 \mathrm{rpm}$ \\
\hline Feed rate VF & $400 \mathrm{~mm} / \mathrm{s}$ \\
\hline Lubrication & in oil \\
\hline
\end{tabular}

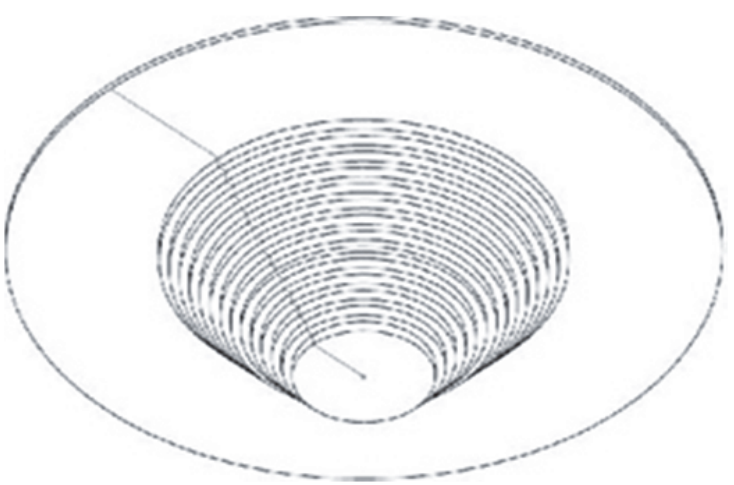

Figure 4. Shape of the bucket to be made and test conditions
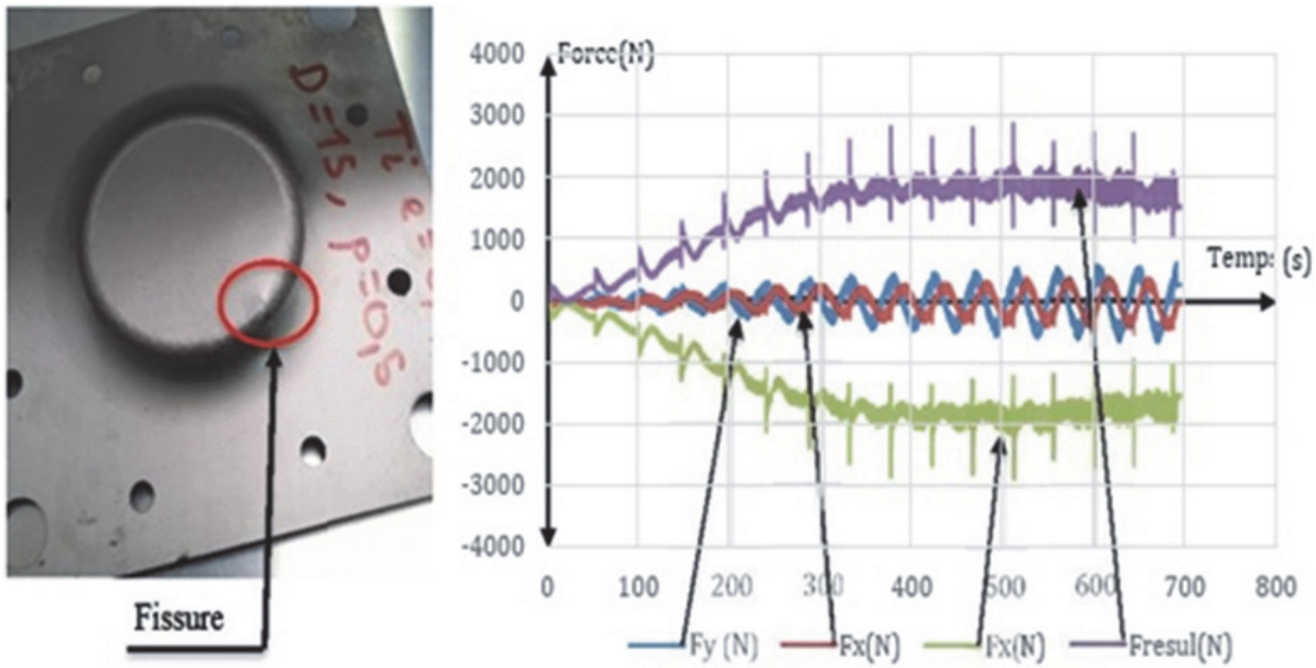

Figure 5. Forming forces for $\Delta \mathrm{z}=0.5 \mathrm{~mm}$ and $\mathrm{dp}=15 \mathrm{~mm}$
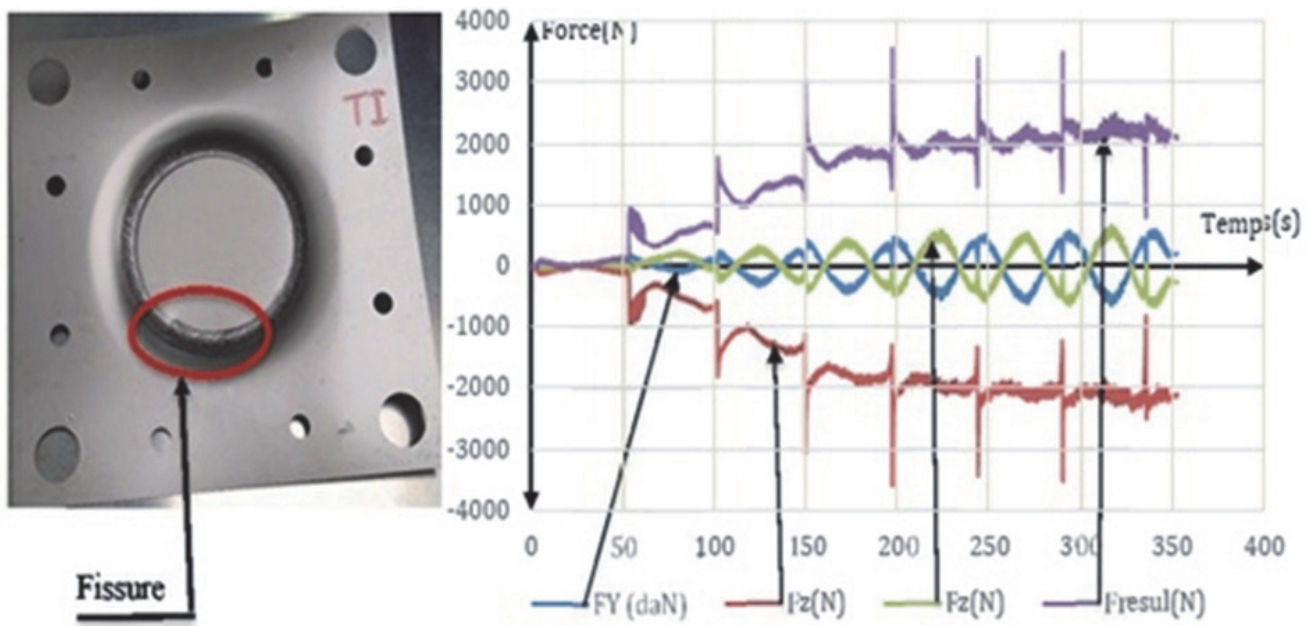

Figure 6. Forming forces for $\Delta \mathrm{z}=1 \mathrm{~mm}$ and $\mathrm{d}_{\mathrm{p}}=10 \mathrm{~mm}$

The numerical simulation of the process was carried out with $\mathrm{ABAQUS} /$ Explicit. A model of elastoplastic behavior ofSwift type $\sigma=\mathrm{K}\left(\mathrm{e}_{0}+\mathrm{e}^{\mathrm{p}}\right)^{\mathrm{n}} \mathrm{is}$ used. The parameters of the model are presented in Table 2.

The sheet with a grid with thin shell elements at 4 nodes has reduced integration of the S4R type. Tools are considered rigid domains. Figure 7 shows the evolution of the forming forces predicted by the numerical simulation. It should be noted that the curves of the numerical prediction are similar to the experimental results, but differences exist and they are linked to the fact that the numerical simulation of the incremental titanium forming process was carried out with a simplified model not taking into account 
Table 2. Plastic properties of grade 2 titanium

\begin{tabular}{|c|c|c|}
\hline $\mathrm{n}$ & $\mathrm{K}$ & $\varepsilon_{0}$ \\
\hline 0.084 & 570 & 0.00157 \\
\hline
\end{tabular}

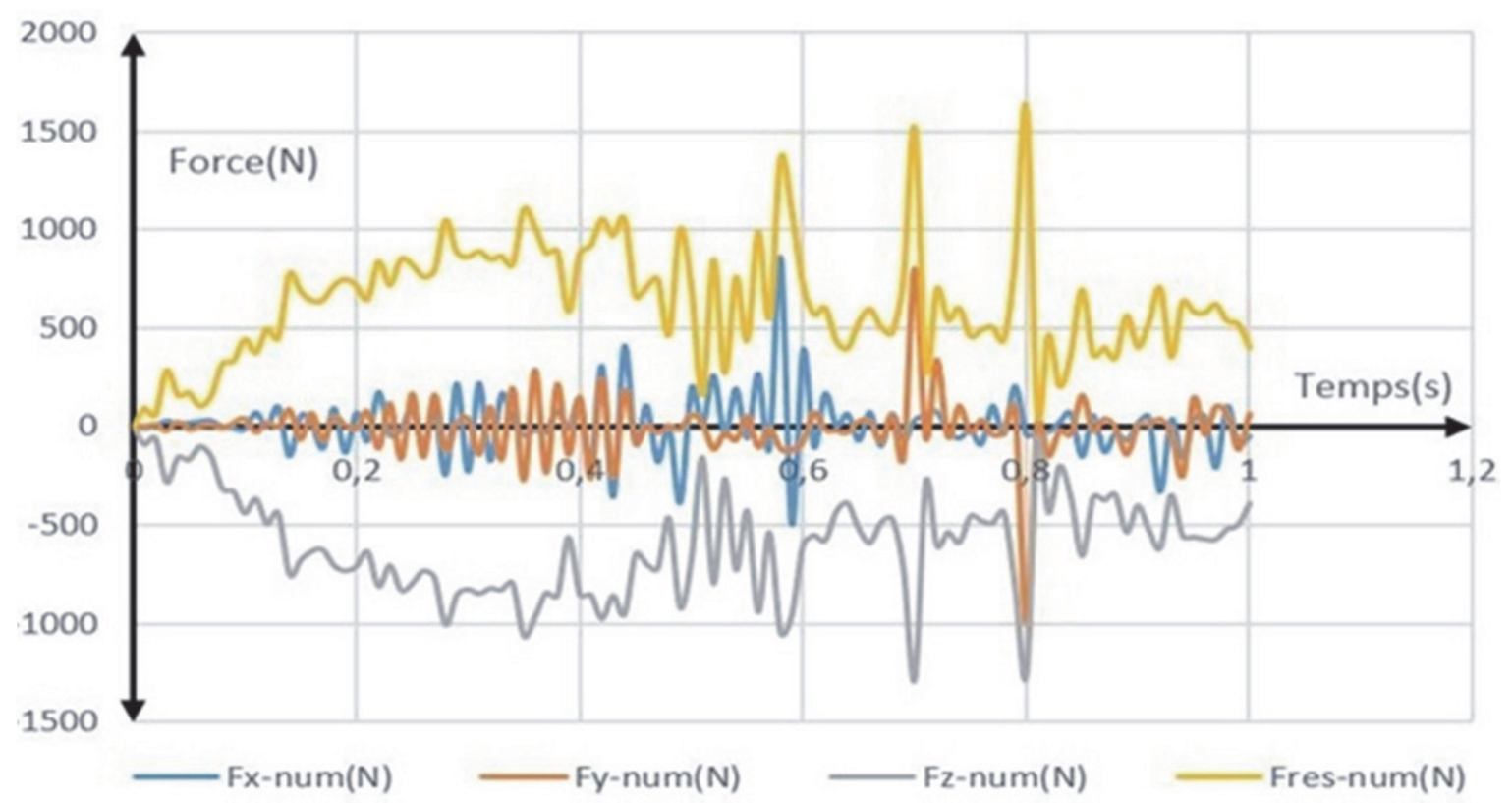

Figure 7. Allure of the forces of the numerical simulation of T40 $\left(e=0.5 \mathrm{~mm} ; d_{p}=15 \mathrm{~mm} ; \Delta z=0.5 \mathrm{~mm}\right)$
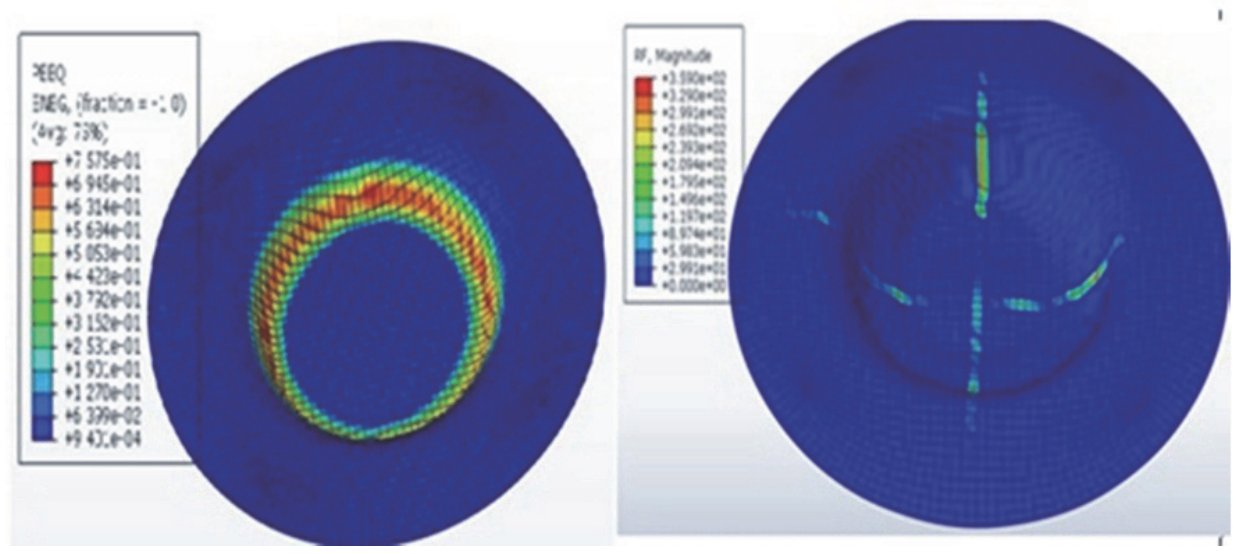

Figure 8. The distribution of the resulting force and plastic deformations
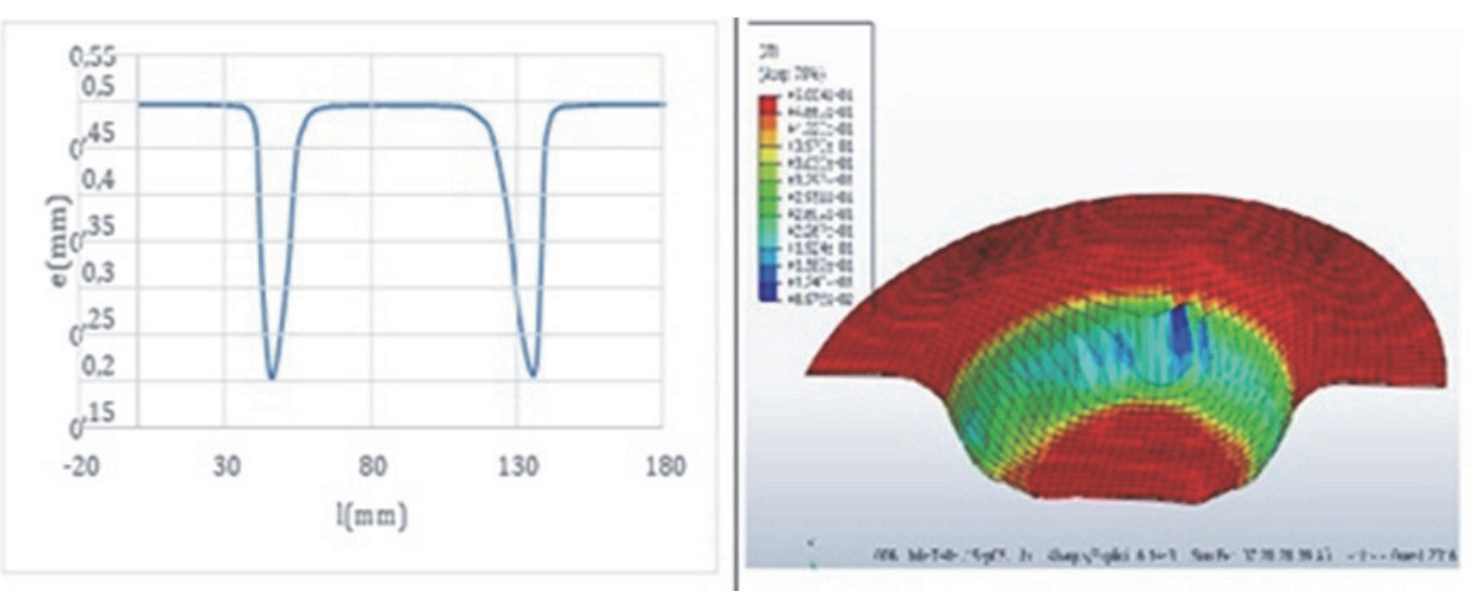

Figure 9. The distribution of the final thickness of the part along the axis of symmetry 
the material anisotropy, damage, blank tightening conditions, tool deformability. The iso-values of the cumulated plastic deformation and the distribution of the final thickness of the part along the axis of symmetry are given in figure 8 . We note a strong localized plastic deformation and a strong thinning on the contour of the bottom of the formed part.

In this paper, an experimental study and numerical simulation of the incremental forming of titanium sheets was carried out. Forming forces are measured experimentally and compared to the values of the numerical prediction. This experimental study showed the need to optimize the process parameters in order to avoid damage to parts and to improve the surface finish of the part. The next work will focus on performing hot tests in order to reduce the forces during the test and increase the ductility of the sheet and improve the thickness distribution.

\section{СПИСОК ЛИТЕРАТУРЫ}

1. Аль Дарабсе А.М.Ф., Маркова Е.В., Миллер В.В. Роль искусственного интеллекта в роботехнике. // В сборнике: Биотехнические, медицинские и экологические системы, измерительные устройства и робототехнические комплексы - Биомедсистемы-2019 Сборник трудов XXXII Всероссийская научно-техническая конференция студентов, молодых ученых и специалистов. Под общей редакцией В.И. Жулева. 2019. С. 638-641.

2. Аль Дарабсе А.М.Ф. Проблемы программного обеспечения в авиационных системах. // В сборнике: Проблемы технического сервиса в АПК Сборник научных трудов II студенческой всероссийской научно-практической конференции. 2019. С. 7-15.
3. Аль Д.А.М.Ф., Маркова Е.В., Вольсков Д.Г. Подрыв конфиденциальности в системе адресации отчетности авиационной связи // В сборнике: Миллионщиков-2019 Материалы II Всероссийской научно-практической конференции студентов, аспирантов и молодых ученых, посвященной 100-летию ГГНТУ. 2019. С. 123-129.

4. Аль Д.А.М.Ф., Маркова Е.В. Система мониторинга работоспособности авиационных газотурбинных двигателей по реальным данным. // В сборнике: Миллионщиков-2019 Материалы II Всероссийской научно-практической конференции студентов, аспирантов и молодых ученых, посвященной 100-летию ГГНТУ. 2019. С. 137-143.

5. Аль Д.А.М.Ф., Маркова Е.В. Особенности снабжения аэрокосмической промышленности // В сборнике: В мире научных открытий Материалы III Международной студенческой научной конференции. 2019. С. 137-140.

6. Маркова Е.В., Аль Дарабсе А.М.Ф., Черненькая Е.В. Форсайт-аудит систем управления в аэрокосмической технологии // Вестник Ульяновского государственного технического университета. 2019. № 1 (85). С. 71-73.

7. Маркова Е.В., Аль Дарабсе А.М.Ф. Влияние инноваций на экономический рост // Вестник Ульяновского государственного технического университета. 2019. № 2 (86). С. 72-74.

8. Аль Дарабсе А.М.Ф., Маркова Е.В. Исследование требований летной годности составных воздушных судов для воздушных судов транспортной категории в FAA // Российский электронный научный журнал. 2019. № 1 (31). С. 8-21.

9. Аль Дарабсе А.М.Ф., Маркова Е.В., Денисова Т.В. Моделирование турбовинтовой гибридной электрической двигательной установки // Российский электронный научный журнал. 2019. № 2 (32). С. 16-33.

10. Аль Дарабсе А.М.Ф. Исследование экономических систем в авиастроении на основе методологии функционально-стоимостной инженерии // В сборнике: Молодежь и наука XXI века Материалы Международной научной конференции. 2018. C. 470-472.

\title{
ЭКСПЕРИМЕНТАЛЬНОЕ И ЧИСЛЕННОЕ ИССЛЕДОВАНИЕ СИЛ ПРИ ИНКРЕМЕНТАЛЬНОМ ФОРМОВАНИИ ТИТАНОВЫХ ЛИСТОВ
}

\author{
() 2021 Е.В. Маркова, А.М. Аль Дарабсе, И.Э. Дабабне, А.Р. Ахмед
}

Институт авиационных технологий и управления, Ульяновский государственный технический университет, Ульяновск, Россия

\begin{abstract}
Постепенное формование - это процесс быстрого прототипирования, который позволяет формовать листы без использования формующих инструментов с помощью станка с числовым программным управлением. С помощью этого процесса можно создавать самые разные формы. Целью данной работы является изучение посредством экспериментальных испытаний и численного моделирования поведения титана марки ASTM 2 во время инкрементного точечного формования (SPIF). Обрабатывающий центр Spinner MFG850 от ISET в JENDOUBA, соединенный с многокомпонентным датчиком силы FN7325, использовался для формования тонких листов с помощью этого процесса. Поскольку диаметр пуансона и его инкрементное перемещение являются параметрами, оказывающими непосредственное влияние на силу формования, были проведены испытания с диаметрами пуансонов dp от 10 до 15 мм и различными траекториями, состоящими из круговых перемещений в горизонтальной плоскости экспериментально. Численное моделирование выполняется при больших упругопластических деформациях с помощью ABAQUS / explicit. Проведены сравнения эволюции формовочной силы для различных значений диаметра пуансона dp и шага перемещения $\Delta \mathrm{z}$.

Ключевые слова: инкрементальная формовка, титан, конечные элементы, эксперименты, приборы. DOI: $10.37313 / 1990-5378-2021-23-1-5-10$
\end{abstract}

\footnotetext{
Маркова Елена Владимировна, кандидат экономических наук, доцент кафедры «Общенаучные дисциплины». E-mail: morozova319@yandex.ru

Аль-ДарабсеАмер Мохаммад, студент группы АСВсд-61 кафедры «Самолетостроение».

E-mail: amersamarah4@gmail.com

Дабабне Исса Эльяс, студент группы АСбд-11 кафедры «Самолетостроение».E-mail: dababneh.issa47@gmail.com Ахмед Ахмед Рамадан, студент группы АСбд-11 кафедры «Самолетостроение».E-mail: flafio5000@gmail.com
} 